\title{
LIVESTOCK HUSBANDRY AND ECONOMIC-SUSTAINABILITY OF SMALL FARMERS IN PERI-URBAN AREAS: A CASE STUDY FROM WEST GOJJAM REGION, ETHIOPIA
}

\author{
*MUSHIR ALI ${ }^{1}$ and MULUGETA NEKA ${ }^{2}$ \\ Doi: http://dx.doi.org/10.4314/ejesm.v5i2.13
}

Received 24th February 2012; accepted

\begin{abstract}
The study attempts livestock husbandry and sustainability of small farmers in West Gojjam region, Ethiopia where a large number of livestock are reared due to the favorable climatic conditions. The mainstay of the population (those with holding of less than $3 \mathrm{ha}$ ) practices mixed crop-livestock farming. It discovers issues of the economic and gender profiles of livestock rearers and their engagement in different operations of livestock husbandry for economic sustainability. Systematic random sampling was applied technique to select 240 households from four micro geographical areas (kebeles) of peri-urban region on the basis of purposive sampling at the distance of 10,20,30, $40 \mathrm{~km}$ from central business district. The findings describe $51.6 \%$ contribution of females in livestock husbandry for barn and cleaning while men performed $71.5 \%$ marketing activities. More than $87 \%$ agricultural operations were done by men using livestock. The Animal husbandry contributes $60-70 \%$ income among the $51.25 \%$ households of small farmers. The growing of income by livestock per year was 6.1\% during 2001-2011. However, ranching of goats and sheep was remarkable for high value added role (11\%) during 2001-11. The study presents recommendations for efficient marketing system, well equipped transportation facilities to improve social-economic sustainability of small farmers.
\end{abstract}

Keywords: work equity, productivity by gender, economic viability and sustainability

\section{Introduction}

Livestock husbandry is one of the important segments of Ethiopian agriculture. It has been practiced as auxiliary activity in the process of production of different food and non-food grains crops since antiquity. Various kinds of livestock such as cattle, buffalo goats, sheep, horses, donkeys are being reared as domestic and subsistence animals with traditional techniques and practices. Except in the case of milk and meat production, commercial form of livestock husbandry rarely existed in Ethiopia. Production has remained at the small scale targeted at meeting local demands. Cattle in subsistence and semisubsistence types of economies have been reared and used mainly to work in agriculture as drought animals. Cow dung is also very valuable that is used as manure and domestic fuels in many rural as well as sub-urban areas. Despite very primitive and traditional form of livestock husbandry, Ethiopia has the largest

${ }^{1}$ Department of Geography and Environmental Studies, Mekelle University, Ethiopia, PB.451,

${ }^{2}$ Department of Geography and Environmental Studies, Bahir Dar University, Ethiopia, PB-79.

*Corresponding email: mushirjbd@gmail.com number of cattle, sheep, goats and poultry in Africa (Wint and Baurn 1994, Lakew et al., 2000, Tassew and Seifu 2009)

After independence Ethiopia witnessed a reform in agriculture, especially in food grain production with the aim of achieving selfsufficiency and for export. However, this objective was never achieved, partly because the imperial colonial and the revolutionary governments failed to implement and accelerate widespread conservation work throughout rural areas. The 1977 famine also provided an impetus to promote conservation. The government mobilized farmers and organized food for work projects to build terraces and plant trees. The Ministry of Agriculture and peasant associations used about 1.2 million ha land for this purpose in the years 1983-84 (Webb 1992). However, the removal of arable land for conservation projects has threatened the welfare for increasing numbers of rural poor and largescale conservation work for environment has 
been ineffective. Consequently, production rate of food grains dropped, the country faced a great food shortage known as food famine, resulted as the death of nearly 1 million people and development of Ethiopian farmers and farming remained imbalanced (Ofcansky and Berry 1993, Leonard 2006).

During the last decades of $20^{\text {th }}$ century, Ethiopian agriculture stood at a crossroad and frustration among farmers as well as in government was inevitable. Food grain production became uneconomical due to increasing gap between input cost and output price per unit weight of its production due to increasing cost of inputs, in successive years under the influence of world economic order. Inefficient agricultural marketing system resulted in low price per unit weight of output. Reduction in the size of operational holdings year after year due to division of holdings among the heirs, drought and soil erosion have also contributed in reduction of productivity. These factors have negatively affected the economic viability of some traditional crops like food grains. This critical agricultural situation called upon a drastic and constructive change in agricultural policies and object orientation of farmers toward diversification of crops and farming systems in the country in recent decades. The agricultural policies in the current decade urged the farmers to move from subsistence traditional cropping system to value added market oriented agriculture and from monoculture to diversified one which is economic viable and environmentally sustainable (Blair 1973, Sere and Steinfeld 1996, Fakoya 2007).

Livestock farming, however, is becoming one of the most important value added farming systems in Ethiopia. It is an important source of food security through meat and milk and other dairy products, which enrich nutritional intake. Increasing urbanization and burgeoning middle class population, improvement in income and socio-economic transformation have expanded the demand of meat and milk products in developing countries, which is expected to double in 20 years and approach to the per capita consumption level of the developed countries by 2020 (Yitaye et al., 2007). This kind of dramatic change in demand and production of livestock and their products is described as Animal Revolution by IFPRI analysts (Delgado et al., 2000). The livestock revolution has offered an opportunity to producers to expand this sector through enhancing production, both in qualitative and quantitative terms. Scaling up of the production and agri-business has also been encouraging advantage for Ethiopia. It is due to optimum distance to Asian (middle-east) and European markets, where livestock products from tropical countries are in great demand. The animal products from Ethiopia have good competitive price in international markets due to low production cost as compared to developed countries (Delgado et al., 2000, Sansoucy et al., 1995, Allana 2005, Picca 2008).

Rural health can be also improved through increasing intake of animal proteins. Addition of livestock manures to the agriculture field also will improve the sustainability of crops. Consequently, an integrated rural development can be obtained through this revolution (Down 1964, Jost 2004).

Livestock revolution has much challenge in the way of achieving successful targets. Intensification and scaling up of livestock and allied industries are usually going to managed by corporate sectors present a threat to the survival of small farmers, enterprises and the ecological balance in the concerned areas (Steinfield et al., 2006, Staal et al., 1997). Increasing pressure of livestock per unit area of pastureland in arid, semi-arid and mountainous regions has accelerated the degree of soil degradation and desertification through over grazing (Lakew et al., 2000). A high demand for feed grains as well fodder has resulted in more hectares of land needed for these crops and, consequently, excess amounts of water are drawn for irrigation with a view to keep up the regular supply of animal feed throughout the year. This pattern of demand for land and water presented a grim situation in food security and water crises during the post economic reform period at a global level. Mismanagement of livestock waste, both solid and liquid, caused soil and water pollution. Global warming is also encouraged through 
livestock and decomposing animal waste (The World Bank, 2006). An animal and human epidemic has also been spreading due to the increase of livestock rearing (Derb, 2005).

However, livestock husbandry, in Ethiopia generate rural employment and enhance incomes of small farmers through job creation in agricultural off seasons. This sector plays a critical role in the welfare of Ethiopian rural population. It contributes about $15 \%$ of gross domestic product (GDP), $10.6 \%$ of export value and employs about $18 \%$ of work force in the country (Ali and Neka 2011). As compared to crop sector, its share in Ethiopian economy has been a good influence over the years. The livestock sector, as being source of flow essential food products, draught power, manures, employment, incomes and export earning, is considered as an important component in poverty alleviation programs (Benin et al., 2002)

Ethiopia in general and in West Gojjam particularly a large livestock population is exit due to the favorable climatic conditions where mainstay of the population is rain-fed subsistence agriculture. About $73 \%$ of smallholders (those have holding less than 3 ha) practice mixed crop-livestock farming, $19 \%$ practice crop cultivation, while the remaining $8 \%$ undertake livestock rearing (Tassew and Seifu, 2009). The precise relationship between opportunities and constraints associated with livestock husbandry about production of milk its products and livestock manures to the agriculture field for improving the fertility of soils is an emerging consensus for livestock husbandry (Alan, 2007).

\section{Objectives of the work}

Keeping the view of importance livestock husbandry and economic-sustainability of small farmers, the researchers conducted work at micro geographical unit Bahir Dar Zuria Woreda (district in the precinct of Bahir Dar), a catchment area of source of the Blue Nile river with the following objectives

- To describe socio-economic profiles of livestock rearers and gender dynamics in livestock allied activities farmer groups employed in various kinds of operations of successful livestock production.

- To examine amount and proportion of income generated from livestock husbandry

- To describe economic sustainability of small farmers livestock production

\section{Geographical outlook of study area}

Bahir Dar Zuria Woreda is situated in west Gojjam region near Lake Tana that is the source of the Blue Nile River and a leading tourist destination in Ethiopia (Ajala, 2008). Its latitudinal and longitudinal extension is $11^{\circ} 25^{\prime} \mathrm{N}-11^{\circ} 55^{\prime} \mathrm{N}$ and $37^{\circ} .04^{\prime} \mathrm{E}-37^{\circ} .39^{\prime} \mathrm{E}$. The district has 32 rural sub-districts (kebeles) with population of 182,730 with 93,642 men and 89,088 women (CSA 2008). Twenty-one per cent the land in Bahir Dar Zuria Woreda is arable, $9 \%$ pasture, $8 \%$ forest or shrub land, $36 \%$ covered with water, and the remaining $26 \%$ is considered degraded (MoARD 2009). Teff, corn, sorghum, cotton and sesame are important cash crops. Majority of population is engaged in primary occupations and $84 \%$ small farmers perform livestock husbandry.

\section{Data Collection}

Owing to paucity of published data on livestock husbandry and economic sustainability of small farmers, the study is based on primary research. The primary data were generated at household level regarding size of operational holding, incomes and gender through the field survey. We selected four kebeles on the basis of purposive sampling at each space of $10 \mathrm{~km}$ distance from the Central Business District (CBD). Information on selected kebeles is given Table 1. Applying systematic (random) sampling technique 240 households (60 from each kebele) were sampled taking into consideration of their socio-economic conditions on the different issues like size of holding, size of family, education, level of employment, income possibility in farming system. The collected data have been processed in tabular form and analyzed with help of statistical techniques and computer cartography.

After determining samples, the sampling of households was conducted calculating the sample for selection next household in each kebele on the basis of the following process. 


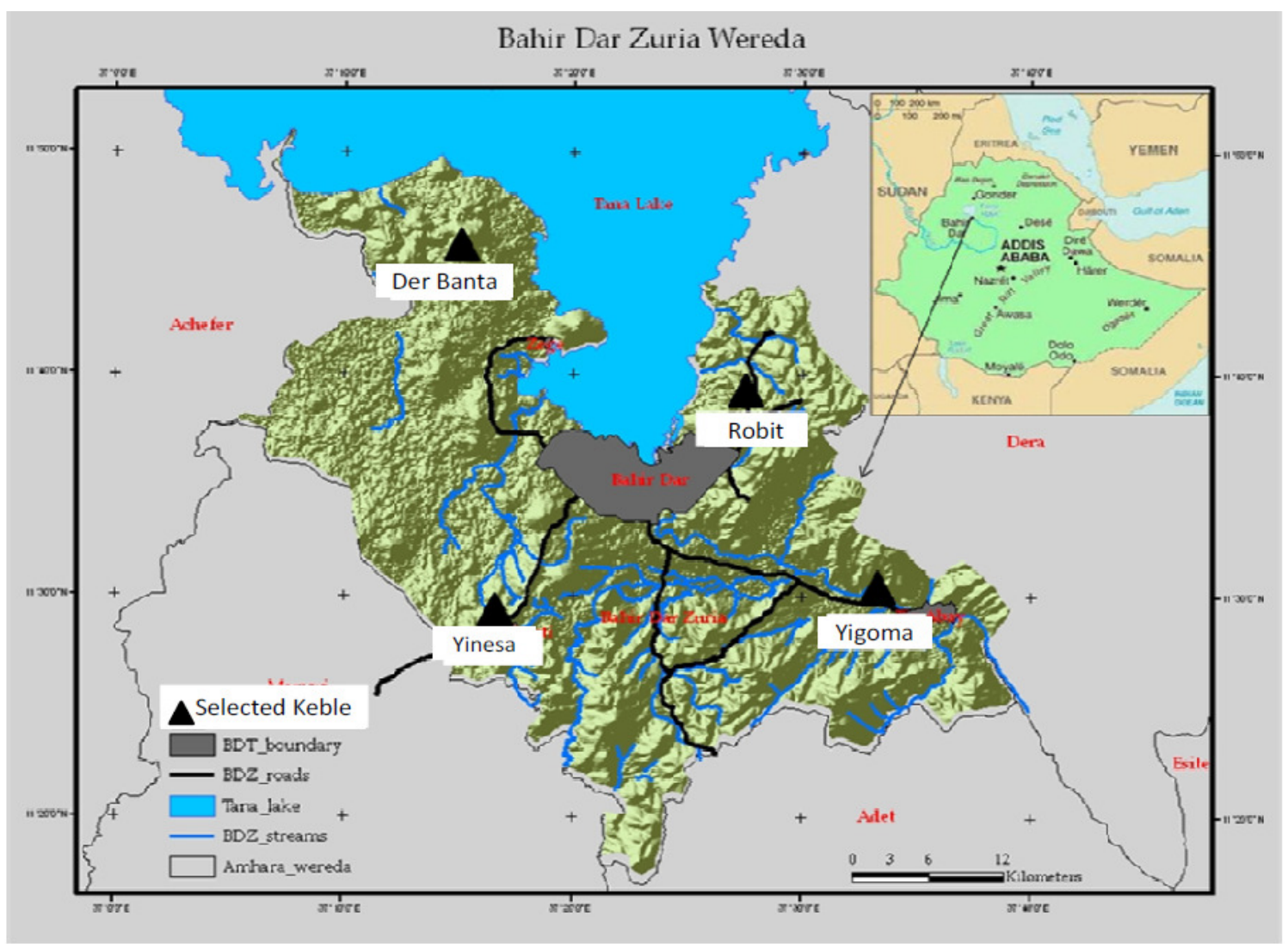

Source: Bahir Dar Land administration, 2011

Figure1 Location of Bahir Dar and Selected Kebeles

Table 1 Basic data of selected kebeles

\begin{tabular}{lccccc}
\hline $\begin{array}{c}\text { Geographical } \\
\text { area }(\text { kebele })\end{array}$ & $\begin{array}{c}\text { Distance from } \\
\text { CBD }(\mathrm{km})\end{array}$ & $\begin{array}{c}\text { Total } \\
\text { households }\end{array}$ & $\begin{array}{c}\text { Total } \\
\text { population }\end{array}$ & $\begin{array}{c}\text { Total male } \\
\text { population }\end{array}$ & $\begin{array}{c}\text { Total female } \\
\text { population }\end{array}$ \\
\hline Robit & 10 & 1916 & 8740 & 4502 & 4238 \\
Yinesa & 20 & 1660 & 8326 & 4351 & 3975 \\
Yigoma & 30 & 1758 & 8357 & 4308 & 4049 \\
Dere Banta & 40 & 657 & 2947 & 1525 & 1422 \\
\hline
\end{tabular}

Source: National Population and Housing Census, Ethiopia, 2007.

Table 2 Procedure for selection of households

\begin{tabular}{cllll}
\hline $\begin{array}{c}\text { Total } \\
\text { households }\end{array}$ & \multicolumn{1}{c}{ Formula } & \multicolumn{1}{c}{ Calculation } & \multicolumn{1}{c}{$\begin{array}{c}\text { Absolute } \\
\text { next sample }\end{array}$} & $\begin{array}{c}\text { Selection of next } \\
\text { household }\end{array}$ \\
\hline 1921 & $\mathrm{~S}=$ th/Th & $1921 / 60=32.02$ & 32 th & $1,33,65 \ldots \ldots$ \\
1748 & Where & $1748 / 60=29.13$ & 29 th & $1,30,59 \ldots \ldots$ \\
1902 & S= sample gap & $1987 / 60=33.12$ & 33 th & $1,34,67 \ldots \ldots$ \\
661 & th=total households of kebele & $661 / 60=11.02$ & 11 th & $1,12,23 \ldots \ldots$ \\
& TH= is target households & & & \\
\hline
\end{tabular}




\section{Result and Discussion}

Profile of livestock ranching duties by gender

Table 3 shows that barn cleaning activities (34.9\%) for livestock is mainly performed by women, followed by boys (23.16\%), men $(19.31 \%)$ and girls $(16.6 \%)$. Women look after them in the home. However, boys do such type of work within and outside of the premises but their participation are lesser than that of women in the home. Milk is considered a main source of nutrition among the poor and women (Jost 2004). Majority of women do milking from cow and shoat (sheep+goat) followed by men, boys and girls while feeding livestock is also performed by women.

Women among households of small farmers not only do livestock ranching work such as barn cleaning, milking and feeding but also they sell milk and its items in the nearby areas and periodic markets to purchase essential commodities of daily use in the kitchen and at the home

Marketing of livestock (71.56\%) is usually performed by men. This is due to the fact that they have good knowledge of livestock, their qualities, type and suitability for agricultural operations. Besides, they are convergent with sell and purchase livestock from the livestock markets and within village and kebele. It is followed by boys $(13.51 \%)$, women $(5.5 \%)$ and girls $(.79 \%)$. women transact livestock in the cases of the female headed households. Boys perform the duty of marketing, if due to health, social and maternal problems, female heads do not able to walk markets places.

Table 3 shows that $87.29 \%$ agricultural work is done by men using livestock among the households of small holders. They use draught livestock in the agricultural operations, i.e. ploughing, seeding, transportation of input and products after harvest. The care related to health of livestock, carrying livestock to veterinary and medicines nearby town, is chiefly acted upon by men $(63.71 \%)$ followed by boys, women and girls respectively. The domination in the selling milk and its items belong to women $(56.78 \%)$.

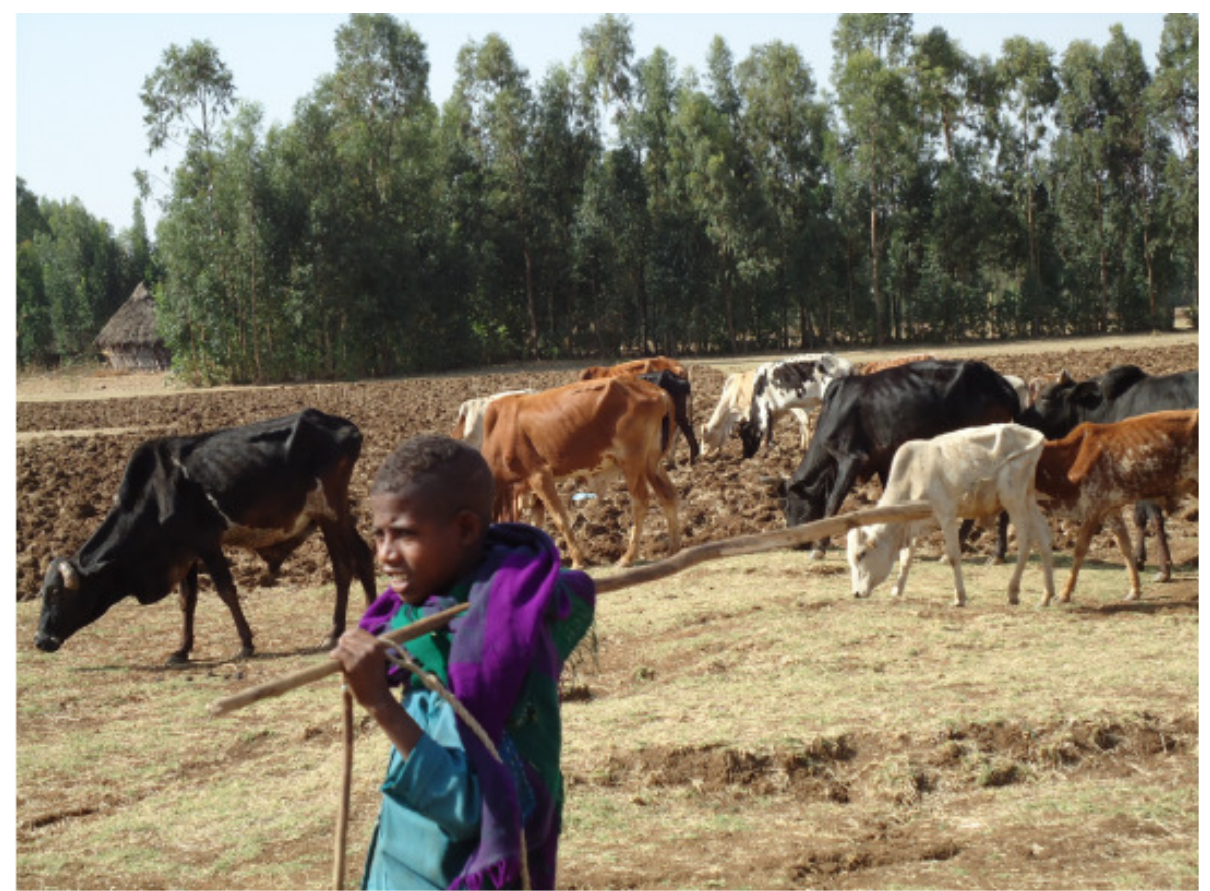

Boy on duty: Grazing cattle in Robit Kebele, Photo by M. Ali 
Table 3 Distribution of Livestock ranching duties by gender

\begin{tabular}{lcccc}
\hline Activities & Men & Women & Boys & Girls \\
\hline Barn Cleaning & 19.31 & 34.90 & 23.16 & 16.60 \\
Milking & 23.33 & 57.78 & 10.00 & 3.89 \\
Feeding & 29.47 & 36.43 & 13.51 & 15.28 \\
Grazing & 25.94 & 13.83 & 33.33 & 17.29 \\
Sell Milk its Items & 19.95 & 56.87 & 11.24 & 2.00 \\
Marketing of Livestock & 71.56 & 5.50 & 13.16 & 0.79 \\
Agricultural Uses & 87.29 & 0.00 & 6.52 & 0.00 \\
Medical Care & 63.71 & 7.62 & 16.41 & 2.77 \\
\hline
\end{tabular}

Source: Field Survey, 2011

* Age group of children (Boys and Girls) is 7-18 years,

** Percentage of total population among 240 sampled households $(\mathrm{N}=1054)$

Educational Profile of Livestock Rearers by Gender

Table 4 shows the educational status of livestock rearers with the majority $(47.38 \%)$ of households being illiterate. Generally, an education level provide understanding to improve the animal rearing for achieving more benefits, particularly in the case of women as they are mainly involved in ranching duties (Table 3). Contrary to this, during field survey it was found that $55 \%$ the women in the sampled households were illiterate. The households' population having primary education occupies first place $26.89 \%$ among literate herders of animals. It is followed secondary education (17.88\%); the persons either only read and write or those not completed their primary school, their share has been reported $5.96 \%$ and senior secondary and above has a tiny proportion.

A majority of population belongs to category of illiterate and below primary education that shows that the people get only lower education and they give more emphasis on livestock rearing and cultivation for their survival and livelihood. The education status among female population is lower than that of male population (Table 4). It also indicates that the females give more emphasis on works related to livestock in the houses and present their strong participation for sustainability of family in regards of social customs, relations and income as well as livelihood.

Table 4 Distribution of Educational Status by Gender

\begin{tabular}{lccc}
\hline $\begin{array}{l}\text { Educational } \\
\text { Status }\end{array}$ & Male & Female & Total \\
\hline Illiterate & 40.00 & 54.60 & 47.38 \\
Under Primary & 7.35 & 4.60 & 5.96 \\
Primary & 30.29 & 23.56 & 26.89 \\
Secondary & 20.00 & 15.80 & 17.88 \\
10+2 and above & 2.36 & 1.44 & 1.89 \\
\hline
\end{tabular}

Source: Field Survey, 2011

* Percentage of total population 7 years \& above $(\mathrm{N}=1054)$

\section{Profile land distribution}

Table 5 shows distribution of holding size among the livestock rearers, the highest (50\%) average proportion of the farmers who have plot size 1-2 ha followed by rearers owners of 2-3 ha and less than 1 ha that varies from kebele to kebele. Dare Banta has a leading share of 1-2 ha holders. It is because these households are situated $40 \mathrm{~km}$ away from Bahir Dar town; they have also livestock in every house. Livestock complement for cultivation of crops and vice-versa. Livestock are used to agricultural operations and deficit period of fodder occurs due to lack of rainfall at mid-April when grasses become arid in the pasture and shrubs and, the agricultural residues work as major diets for livestock. 
Table 5 Distribution of land area owned by livestock rearers

\begin{tabular}{lccc}
\hline Selected kebeles & $\begin{array}{c}\text { Size of Holding } \\
(0-1 \mathrm{ha})\end{array}$ & $\begin{array}{c}\text { Size of Holding } \\
(1-2 \mathrm{ha})\end{array}$ & $\begin{array}{c}\text { Size of Holding } \\
(2-3 \mathrm{ha})\end{array}$ \\
\hline Robit & 20.00 & 46.67 & 33.33 \\
Yinesa & 26.67 & 36.67 & 36.67 \\
Yigoma & 23.33 & 46.67 & 30.00 \\
Dere Banta & 20.00 & 50.00 & 30.00 \\
Average & 22.50 & 45.00 & 32.50 \\
\hline
\end{tabular}

Sampled households $(\mathrm{N}=240)$

\section{Changes in Livestock Population}

Figure 2 shows change in livestock population among the sampled households in study region. It was reported during field survey that cow were reared 438 heads in 2001 and their number decreased 304 heads in 2011 with rate (-3.13 per annum) among the sampled households. It was due to shrinking of grazing land and economic causes, i.e. majority of cow belong to indigenous species were herded for milk purpose. But declining amount of milk in a lactation period of the cow, lack of proper marketing from the villages to regional and terminal markets, lack of modern preservation facilities for milk due to poor level of infrastructural in the study area, they were losing their economic importance. So, it was noted from the sampled households by discussion that reares are not giving preference to cow husbandry.

However, the decreasing the population of ox was not alarming, it was slightly with the rate $(-0.3 \%)$ among the sampled households in the study area. They were 411 heads in 2001 and 399 heads in 2011. Because small farmers (holders till $3 \mathrm{ha}$ ) use the ox in agricultural operations, i.e. ploughing field, sowing, transportation of input and output of crops, threshing the harvested crops and so on. Besides, there is returning value is comparatively higher than that of cow from markets where they are easily sold at good and lucrative prices (Ali, 2010).

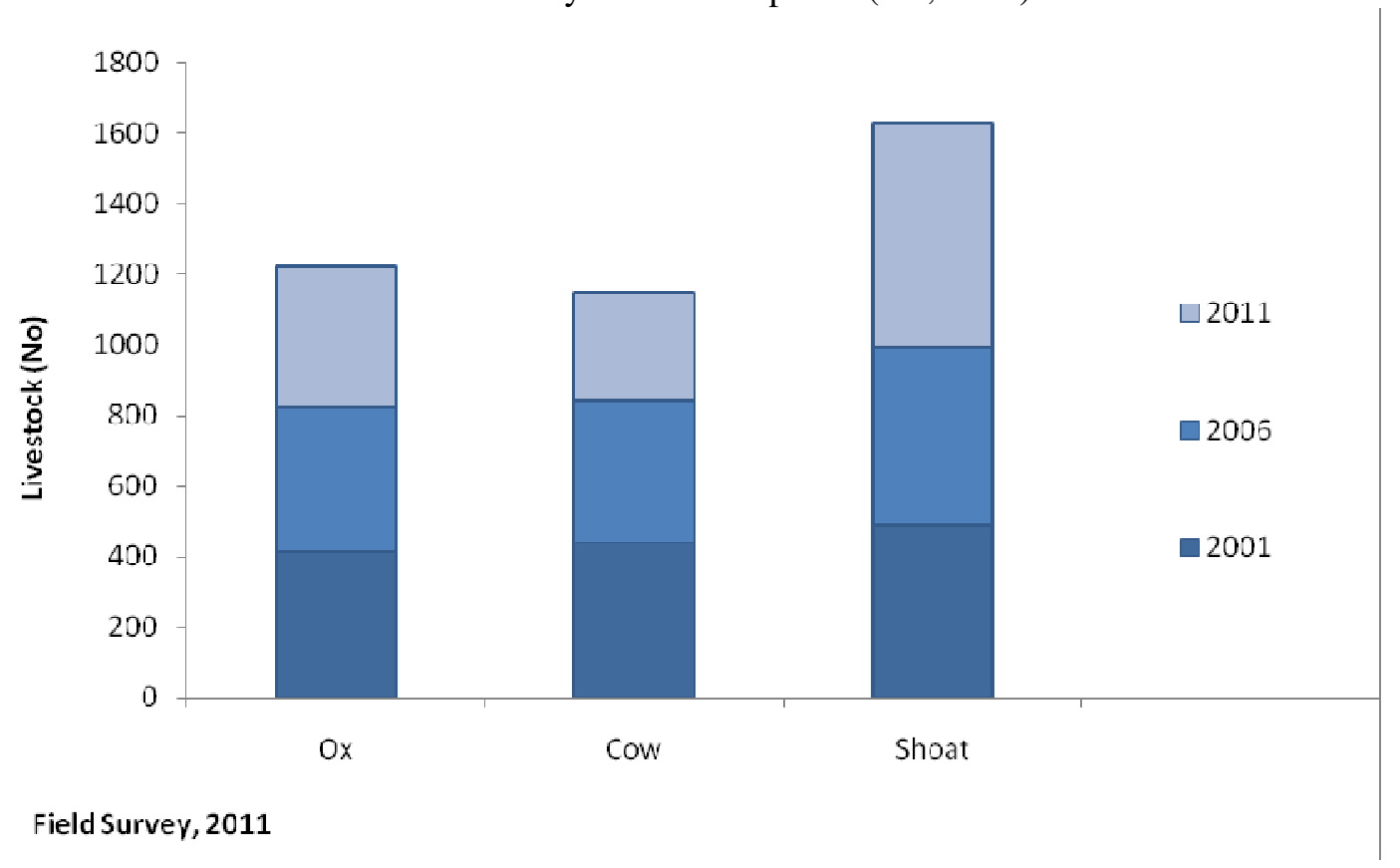

Figure 2 Change in Livestock Population, 2001-2011 
Moreover, it was observed during tield survey that the population of sheep and goats increased among the sampled households. The enhancement rate has been calculated $5.23 \%$ during 2001 to 2006 and $5.4 \%$ during 2006 to 2011. This is because the sheep and goats require relatively smaller area for rearing, and can be easily handled by women and children. They also provide quick cash whenever, they are sold. It is due to increasing demand of mutton for consumption among restaurants, individuals and groups in the Bahir Dar town and its peri-urban areas.

Livestock Husbandry and Employment for Small Farmers

Livestock husbandry is considered as an integral part of the small farmers' economy. It was assessed during field survey among the sampled households. With regards to employment $50.71 \%, 41.90 \%$ and contained $7.38 \%$ of the farmers were involved in agriculture, animal rearing and casual respectively.

Total working population (18-59 years) among sampled households ( $\mathrm{N}=768)$

Table 6 shows that agriculture is main source of employment for a majority working population $(50.7 \%)$, followed by animal rearers $(41.9 \%)$, agricultural/casual labourers (7.38\%). Agriculture as an occupation is recognized on the basis of a person who is engaged in cultivation on own/leased land more than 180 days in a year. However, production of this sector is not sufficient, due to lack of irrigation facilities. In the whole region rain-fed agriculture is in practice that depends on the summer rainfall. However, absence of industrial development and unavailability of services, working population is affianced mainly in farming, but due to less than 100 working days in agriculture, they have been counted as agricultural labourers. Agricultural/casual labourers were observed at critical position regarding livelihood, generally during lean agricultural seasons or not availability of work in other sectors. Livestock rearing is lucrative employment for small farmers because demand of livestock is increasing in urban areas for meat and milk with improvement in income and changing dietary behavior for animal protein (Kamarao 2005).

\section{Role of Livestock Husbandry in Income of Small Farmers}

Livestock husbandry contributes $60-70 \%$ income for $51.25 \%$ households of small farmers. $29.1 \%$ small farmers get share of their income $50-60 \%$, the lowest share $(19.75 \%)$ support to $40-50 \%$ income.

Table 6 Employment of Small Farmers involved in livestock husbandry

\begin{tabular}{lccc}
\hline $\begin{array}{l}\text { Selected } \\
\text { kebeles }\end{array}$ & Cultivators & $\begin{array}{c}\text { Animal } \\
\text { Rearers }\end{array}$ & $\begin{array}{c}\text { Agricultural/ } \\
\text { Casual } \\
\text { labourers }\end{array}$ \\
\hline Robit & 50.00 & 40.74 & 9.26 \\
Yinesa & 48.28 & 44.83 & 6.92 \\
Yigoma & 52.92 & 37.46 & 9.62 \\
DereBanta & 52.26 & 44.48 & 3.26 \\
Average & 50.71 & 41.90 & 7.38 \\
\hline
\end{tabular}

Table7 Distribution of Livestock Husbandry by Annual Income of Small Farmers

\begin{tabular}{lccc}
$\begin{array}{l}\text { Selected } \\
\text { kebeles }\end{array}$ & $\begin{array}{c}\text { Low } \\
(40-50 \%)\end{array}$ & $\begin{array}{c}\text { Medium } \\
(50-60 \%)\end{array}$ & $\begin{array}{c}\text { High } \\
(60-70 \%)\end{array}$ \\
\hline Robit & 22.00 & 32.29 & 45.71 \\
Yinesa & 19.29 & 23.57 & 57.14 \\
Yigoma & 25.00 & 36.11 & 38.89 \\
DereBanta & 12.71 & 24.43 & 62.86 \\
Average & 19.75 & 29.1 & 51.15 \\
\hline
\end{tabular}

Source: Field Survey, 2011

*Sampled households $(\mathrm{N}=240)$

This contribution varies kebele to kebele. The highest share $(62.86 \%)$ in the high category (share of income 60-70\%) has been recorded among households (62.86\%) in Dare Banta kebele. There are livestock mainly used for agricultural operations, ploughing fields, carrying water from surrounding springs and streams on the back of livestock for irrigation of crops where agricultural fields are situated on the highlands than water bodies. No mechanical technique has been introduced to lift up water for the irrigation purpose from low laying water sources. Moreover, dung of livestock is used to maintain fertility of the soil either by directly dump dung as manure in the fields or by producing the compost by the traditional method. Livestock are also 
considered as major sources of nutritional security at household level. Their milk and meat are consumed as chief items of diets of the family except fasting days (Friday and Wednesday) in a week and a fasting period of 55 days from $24^{\text {th }}$ February to the Easter $22^{\text {nd }}$ April each year (Aymero and Joachim 1970). The small farmers rear livestock in the houses for selling mainly on the occasion of Easter at good lucrative prices to add to their annual income. The lowest share of livestock in income has been recorded in Yigoma kebele, where due to availability of micro irrigation facilities small farmers give more emphasis to produce value added cash crop, Chat which is demanded at surrounding spaces at higher prices.
Fig 3 shows that livestock contributes for growing income per year average $6.1 \%$. Instead of decreasing livestock heads. Goats and sheep provide continuous availability of progress number and value (11\%) during 2001-11 because, they are reared to get easy and quick cash, and are often slaughtered to sustain nutritional security of the family members. By oxen income growth was $6.6 \%$ per year during 2001-2011 because in the study area the farmers mainly used them for agricultural operations. However, the contribution of cow is the lowest because they are mainly reared for milk or to add new head for the cattle species. It was noted during the field survey that people are going to more conscious for their economic sustainability. That is why they prefer to rearing of sheep and goats, instead of cow.

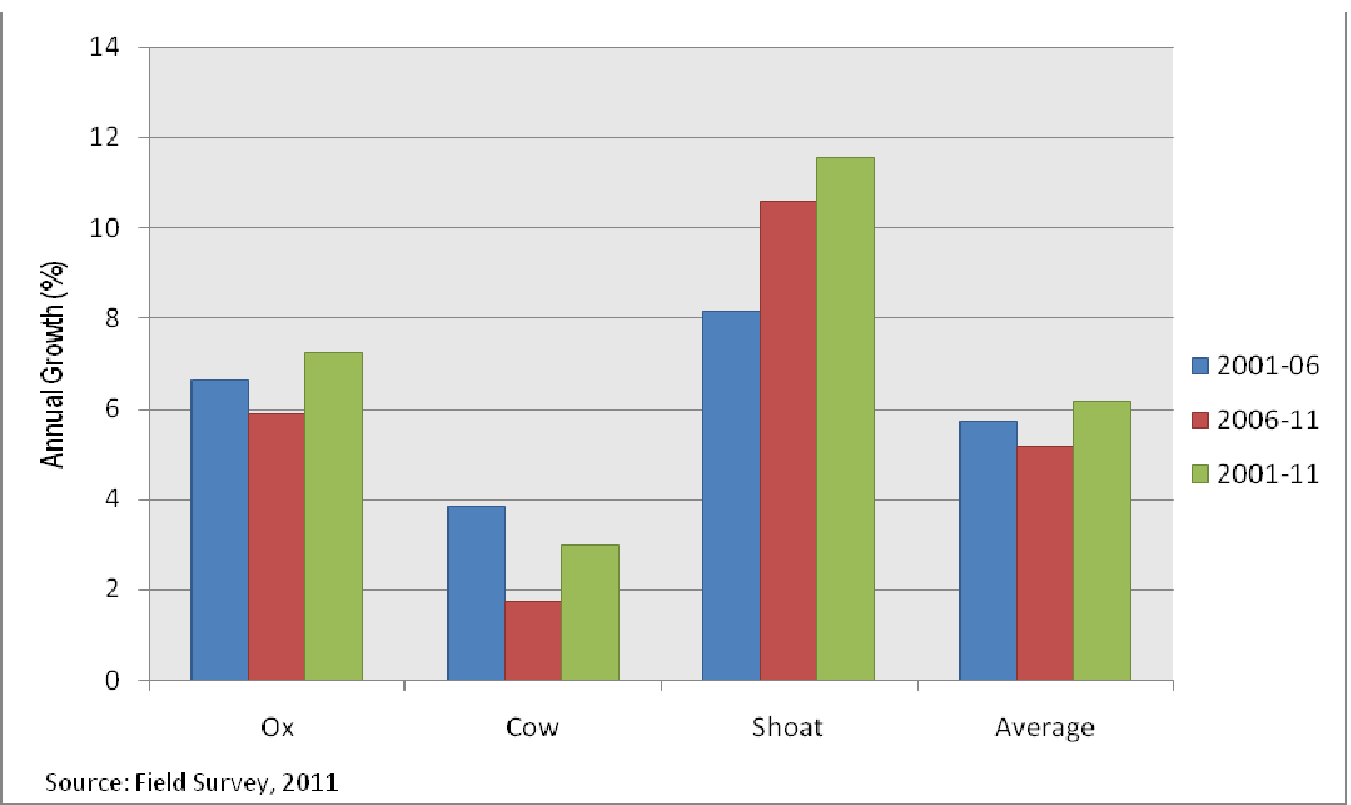

Figure 3 Effects of livestock husbandry on income of small holders, 2001-2011

\section{Conclusions}

In livestock husbandry majority of women equally involved to perform tasks including milking, barn cleaning; feeding of the livestock. The grazing of livestock is usually supervised by boys. Marketing and medical care duties for livestock are performed by men. Illiteracy and poor education are common for livestock rearers due to more emphasis on their survival and livelihood. The highest share of livestock rearers who have plot size 1-2 ha but it varies kebele to kebele. There was negative growth among cow and oxen contrary to it positive enhancement in goats and sheep, due to providing quick cash. Livestock husbandry is an integral part of the small farmers' 
economy that involves animal rearing. It contributes $60-70 \%$ income for majority households. A big share of livestock are used for agricultural operations; ploughing fields, and carrying water from surrounding springs and streams on the back of livestock for irrigation, dung of livestock to maintain environmental sustainability as fertility of the soil. Overall, in spite of decreasing the total number of livestock, their contribution for income of small holders is positive. The effect of livestock husbandry on the annual growth of income was the highest in the cases of goats and sheep followed by ox. Livestock rearers are going to be conscious for their economic sustainability so they prefer to rear sheep and goats, instead of cow. However, to add a dimension for social-economic sustainability of small farmers, efficient marketing system, well equipped transportation facilities are urgently needed.

\section{References}

Ajala, O.A. (2008). "Employment and Income Potentiality of Tourism Development in Amhara Region" Ethiopia, Ethiopian Journal of Environmental Studies and Management, Vol.1 (2):74-82.

Alan, F. (2007). "Soil physical Aspects of Integrated Crop-Livestock Systems". Proceeding of Symposium on integrated CropLivestock Systems. Curitiba, Brazil.

Ali, M. and Neka, M. (2011). "Livestock husbandry and its effect on economic wellbeing of small farmers in peri-urban areas of Bahir Dar town". Unpublished Research Project Report, Bahir Dar University, Ethiopia.

Ali, M. (2010). "Impact of Natural and Anthropogenic Environment on Livestock Husbandry: A Case study". In Global Warming: An Overview, eds K.K. Misra and P. Mishra: 43-49. Committee on Human Development. Orai, India

Allana, I. (2005). "Current Scenario and Growth Prospects for Meat and Rising India's Share in Global Markets." presented at Agriculture Summit, New Delhi: Vigyan Bhavan, April 9-10, 2005.
Aymero, W. and M. Joachim, eds. (1970). The Ethiopian Orthodox Church. Addis Ababa: the Ethiopian Orthodox Mission.

Benin, S., Ehui, S. and Pender, J. (2002). "Policies for Livestock Development in the Ethiopian Highlands." Socio-economic and Policy Research Working Paper. Livestock Policy Analysis Program. Addis Ababa: International Livestock Research Institute (ILRI).

Blair, R.A. (1973). "Notes on Livestock Production" in Symposium on Drought in Africa." London: School of Oriental and African Studies, University of London.

CSA (2008). Central Statistical Authority, Addis Ababa

Delgado, C.L., Rosegrant, M.W., Steinfeld, H., Ehui, S. and Courbois, C. (2000). The Coming Livestock Revolution, International Food Policy Research Institute (IFPRI), Paper No6. Commission on Sustainable Development, Eighth Session, 24 April - 5 May 2000, New York

Derb, Y. (2005). "Study on Endoparasites of Dairy Cattle in Bahir Dar and It's Surrounding." DVM Thesis, Faculty of Veterinary Medicine, Addis Ababa University, Debre Zeit, Ethiopia.

Down, J.E. (1964). "Livestock Production and Social Mobility in High Altitude Tibet." American Anthropal, Vol. 65:1115-19.

Fakoya, E. O. (2007). "Utilization of Croplivestock production systems for sustainable agriculture in Oye state, Nigeria". Journal of Social Science, Vol. 15(1): 31-33.

Jost, C. (2004). "Men, Women, Children and Livestock: A Livelihood Analysis of Region Kuchi, focused on Gender and Animal Health." Kabul: GRM, Internationa, 37.

Lakew, D., M. Kassie, S. Benin. and J. Pender. (2000). "Land Degradation and Strategies for Sustainable Development in the Ethiopian Highlands: Amhara Region". Socio-economic and Policy Research Working Paper.32:122. ILRI (International Livestock Research Institute), Nairobi, Kenya. 
Leonard, D. K. (2006). “The Political economy of International development and Pro- Poor Livestock policies". A Comparative Assessment, Pro-Poor Livestock Initiatives Working Paper, 35, FAO.

MoARD (2009). "Amhara Livelihood Zone, Reports- Bahir Dar Zuria Woreda West Gojam Administrative", the Ministry of Finance and Economic Development Addis Ababa.

Ofcansky, T.P. and Berry, L. eds. (1993). "Ethiopia: A Country Study". Washington D.C, Federal Research Division, Library of Congress.

Picca, C. U. (2008). "Livestock Policy for Poverty Alleviation. Theory and Practical evidence from Africa, Asia and Latin America". Pro-Poor livestock Initiative Revija za geografijo- Journal for Geography, Vol. 5 (2).

Ramarao, W. Y. (2005). "Crop-Livestock integrated farming system for augmenting socio-economic status of small holder tribal farmers of Chattisgarh in centra" .Working Paper No. 27, FAO.

Sansoucy, R., Jabbar, M., Ehui, S. and Fitzhugh, H. (1995). "The Contribution of Livestock to Food Security and Sustainable Development. In Livestock Development Strategies For Low-Income Countries. R. Wilson, S. Ehui and S. Mack (eds), Proceedings of the joint FAO/ILRI Roundtable on Livestock Development Strategies for LowIncome Countries, 27 Feb-2 March 1995. Addis Ababa: ILRI

Sere, C. and Steinfeld, H. (1996). "World Livestock Production Systems: Current Status, Issues and Trends." FAO Animal Production and Health Paper 127:82. Rome.

Staal, S., Delgado, C. and. Nicholson. C. (1997). "Smallholder Dairying under
Transaction Costs in East Africa." World Development 25: 779-94.

Steinfeld, H., Gerber, P. Wassenaar, T. , Castel, V., Rosales, M. and Haan, C.D. (2006) "Livestock's Long Shadow. Environmental Issues and Options," LEAD/FAO, Rome, ISBN 978-92-5-1055717.

Tassew, A. and Seifu, E. (2009). "Smallholder Dairy Production System and Emergence of Dairy Cooperatives in Bahir Dar Zuria and Mecha Woredas, Northwestern Ethiopia", World Journal of Dairy \& Food Sciences, 4 (2): 185-92.

The World Bank (2006). "Managing the Livestock Revolution. Policy and Technology to Address the negative Impact of Fast Growing Sector". The World Bank Agriculture and Rural development Department. Report No. 32725-GLB: 6

Webb, P., von Braun, J. and Yohannes, Y. (1992). Famine in Ethiopia: Policy Implications of Coping Failure at National and Household Levels. Washington, DC: International Food Policy Research Institute. ISBN 0-89629-095-6.

Wint and D. Baraun. (1994). An Anthropogenic and Environmental Correlates of Livestock Distribution in Sub-Saharan Africa. Oxford: U.K. Oxford Environmental Research Group.

Yitaye, A., Wurziger, M., Azage, T. and Zollitsch, W. (2007). "Urban and Peri-urban Farming Systems and Utilization of the Natural Resources in the North Ethiopian Highlands." In Proceeding of Conference on International Agricultural Research for Development. Germany, 9-11 Oct. 2007, University of Kassel-Witzenhausen and University of Gottingen. 